\title{
STILISTIKA DALAM PUISI “TASBIH" KARYA EMHA AINUN NADJIB
}

\author{
STILISTIKA IN TASBIH POEM \\ BY EMHA AINUN NADJIB
}

\author{
Rita Novita \\ Balai Bahasa Provinsi Sumatera Barat, \\ Pos-el lesha_one@yahoo.com
}

\begin{abstract}
This paper present an analysis of stilistika in poem "Tasbih" Emha uses neutral words with religius meaning. One of the factors that couse of its religiousness arise because of the mulitude of human being who have renounced the religiusness. Furthermor, although it does not countain, but it has a deep meaning. Emha also does too many gramatical irregularities to produce an effect of his poetry.
\end{abstract}

Key words: stilistika, religius, poem, meaning

\begin{abstract}
Abstrak
Makalah ini menyajikan analisis stilistika terhadap puisi Tasbih karya Emha Ainun Nadjib. Berdasarkan hasil analisis ditemukan bahwa puisi Emha menggunakan kata-kata yang kental dengan makna religius. Salah satu faktor yang dapat menyebabkan keregiliusan muncul karena banyaknya manusia yang telah meninggalkan dunia kereligiusan. Selanjutnya, walaupun puisi ini tidak banyak mengandung majas, tetapi ia memiliki makna dalam. Emha juga melakukan penyimpangan tata bahasa untuk menghasilkan efek puitis terhadap karyanya.
\end{abstract}

Kata kunci: stilistika, religius, puisi, makna

\section{Pendahuluan}

Pandangan bahwa bahasa sastra adalah bahasa yang khas sudah tersebar luas, kuhusnya puisi dianggap umum menunjukkan pemakaian bahasa yang spesial yang hanya dimanfaatkan oleh penyair. Pemakaian bahasa tersebut sering menyimpang dari bahasa sehari-hari dan bahasa yang normal (Teeuw, 2003: 59). Puisi merupakan salah satu karya sastra yang dapat memberi kehangatan, ketenteraman, tawa; ia juga dapat membangkitkan, menenangkan, dan menghibur. Hal tersebut terjadi karena permainan kata dalam puisi. Di samping itu, penyusunan, pemilihan kata, penekakan, serta kepadatan puisi juga sangat menentukan suasana yang dikandungnya (Sarumpaet, 2002: 1-3).

Bahasa puitik berhubungan dengan masalah yang ada dalam struktur verbal, seperti halnya analisis lukisan mengenai struktur lukisan. Karena linguistik merupakan pengetahuan yang menyeluruh tentang struktur verbal, bahasa puitik dapat dianggap sebagai bagian yang tidak terpisahkan dari linguistik. Saranasarana yang digunakan dalam bahasa puistik tidak terbatas pada seni verbal saja (Sudjiman, 1992: 64). Persoalan yang berhubungan dengan bahasa merupa- 
kan aspek yang berkaitan dengan stilistik, sedangkan pesoalan karangan berkaitan dengan teknik (Yunus, 1989: x).

Persoalan pilihan kata bukanlah persoalan yang sederhana. Ketika akan menyampaikan suatu gagasan, seseorang akan memilih kata-kata yang tepat untuk menyatakan gagasan tersebut. Seorang yang miskin akan kosakata akan sulit menemukan kata tersebut. Ia tidak mengatahui bahwa ada kata lain yang lebih tepat dan ia tidak mengetahui bahwa ada perbedaan antara kata-kata yang bersinonim. Pemilihan kata juga mencakup fraceologi, gaya bahasa, dan ungkapan. Di samping itu, ia juga harus memperhatikan apakah kata yang digunakan dapat juga diterima atau tidak merusak suasana yang ada. Kata yang digunakan hendaknya cocok atau serasi dengan norma-norma masyarakat dan harus sesuai dengan situasi yang dihadapi (Keraf, 2000: 85). Emha dapat dikatakan ahli dalam memlilih kata yang dapat menyentuh perasaan pembacanya. Oleh sebab itu, penulis akan melihat stilistika yang terdapat dalam salah satu puisi religuiusnya, yaitu "Tasbih".

Berikut ini kutipan puisi yang berjudul 'Tasbih" karya Emha Ainun Nadjib dari kumpulan puisinya yang berjudul Doa Mencabut Kutukan, Tarian Rembulan, Kenduri Cinta (2001: 145).

\section{Tasbih}

Seluruh hamba di langit dan bumi

Bertasbih kepadaMu malam ini

Para kekasih yang melata, yang merangkak yang berdiri, yang duduk, yang berjalan Bertakbir kepadaMu dalam sunyi

\section{Bukan hanya kami para khalifah}

Namun juga seluru alam, rembulan cahaya dan keremangan, angin, tanah logam, pepohonan,suara, musik

Semuanya menyujudi keindahanMu

Ribuan hamba, jutaan fakirmu

Bareng-bareng mengeja kata perjuangan

Tidak untuk menang atas orang lain.
Tidak untuk unggul atau menggagahi siapapun

Melainkan berupaya mempertengkari

diri mereka sendiri

Berupaya untuk meremehkan nafsu

Mencoba bersikap acuh pada setiap pemilikan

Selain atas ridhaMu

Dunia begini gagah, namun maya

Sejumlah kemajuan terbentur kebodohan

Berbagai kepintaran terjebak kebodohan

Yang kami sangka kami miliki

Ternyata memperbudak kami

Jakarta, 1995

(Tarian Rembulan: 145)

Emha Ainun Nadjib lahir di Jombang, 27 Mei 1953, anak ke-4 dari 15 bersaudara. Pendidikan formalnya hanya berakhir di semester 1 Fakultas Ekonomi, Universitas Gadjah Mada (UGM) Yogyakarta. Sebelum itu, ia dikeluarkan dari Pondok Modern Gontor Ponorogo karena "demo" melawan keamanan pada pertengahan tahun ketiga studinya. Kemudian, ia pindah ke Yogyakarta dan dapat menamatkan studinya di SMA Muhammadiyah I. Lima tahun hidup menggelandang di Malioboro Yogyakarta antara tahun 1970 - 1975 ketika belajar sastra kepada guru yang dikaguminya, Umbu Landu Paranggi, seorang sufi yang hidupnya misterius dan sangat mempengaruhi perjalanan Emha (http:// www.royahmadsketsa.wordspress).

Emha atau yang lebih akrab dengan panggilan Cak Nun merupakan budayawan dan intelektual muslim. Sebelum menikah dengan Novia Kolopaking, Cak Nun pernah menikah dan dikarunia seorang anak, yang merupakan vokalis dari grup band Letto. Pernikahannya dengan Novia Kolopaking dikarunia dengan empat orang anak (http:// profil.merdeka.com/indonesia).

Emha terjun langsung di masyarakat dan melakukan aktivitas-aktivitas yang merangkum dan memadukan dinamika kesenian, agama, pendidikan politik, sinergi ekonomi, yang berintikan upaya penum- 
buhan potensialitas rakyat. Di samping aktivitas rutin bulanan dengan komunitas Masyarakat Padang Bulan di sejumlah kota, ia juga diminta berkeliling ke berbagai wilayah seluruh nusantara, rata-rata 10 - 15 kali per bulan bersama Musik Kiai kanjeng. Emha mengumpulkan semua golongan, aliran, kelompok, agama, berdasar kegembiraan menikmati kebersamaan kemanusiaan. Dalam pertemuan-pertemuan sosial itu ia melakukan berbagai dekonstruksi pemahaman atas nilai-nilai, pola-pola komunikasi, metode perhubungan kultural, pendidikan cara berpikir, serta pengupayaan solusi-solusi problem masyarakat.

Ia juga pernah mengikuti lokakarya teater di Filipna (1980), International Writing Program di Universitas Lowa, Lowa City AS (1984), Festival Penyair Internasional di Rotterdam (1984), dan Festival Horizonte III di Berlin barat, Jerman pada tahun 1985 (http://wwwroyahmadsketsa.wordspress).

\section{Bunyi dan Bahasa dalam Sajak}

Bunyi dalam Sajak terkait dengan berberapa unsur, yaitu 1) irama, 2) kakafoni dan efoni, 3) onomatope, 4) asonansi, 5) anafora, dan epifora. Irama merupakan bunyi yang teratur, terpola, dan menimbulkan variasibunyi sehingga menimbulkan suasana. Metrum adalah irama yang tetap, terpola menurut pola tertentu dan ritme adalah irama yang disebabkan pertentangan atau pergantan bunyi tinggi rendah secara teratur, tetapi tidak merupakan jumlah suku kata yang tetap dan hanya menjadi gema dendang penyair. Kakafoni dan efoni adalah pemanfaatan bunyi sedemikian rupa sehingga bunyi yang dirangkai di dalam sajak dapat menibulkan kesan yang cerah atau sebaliknya. Onomatope adalah salah satu pemanfaatan unsur bunyi yang cukup dominan di dalam sajak. Asonansi merupakan pemanfaatan unsur bunyi secara berulang-ulang dalam satu baris sajak. Beberapa pengertian tersebut dapat kita temuakan dalam Hasanuddin (2001: 56-78).

Selanjutnya, Bahasa dalam sajak dapat juga kita liat dari berbagai aspek, yaitu 1) kosakata, 2) pemilihan kata atau diksi, 3) pencitraaan atau pengimajian, 4) bahasa bermajas, 5) bahasa retorika, 6) tata bahasa. Kosa kata adalah bagaimana kata-kata yang terdapat dalam sebuah puisi. Pemilihan kata atau diksi adalah bagaimana pemilihan kata setepat mungkin untuk mengungkapkan gagasan. Pengimajian adalah pemilihan terhadap kata tertentu yang akan menyebabkan timbulnya daya saran yang menyebabkan daya bayang pembaca terhadap sesuatu hal. Bahasa bermajas adalah pemanfaatan satu sarana kebahasaan untuk menciptakan unsur kepuitisan, yaitu bahasa bermajas. Tata bahasa adalah penyalahan tata bahasa untuk menimbulkan kesan kepuitisan. Beberapa pengetian tersebut juga dapat kita temukan dalam Hasanuddin (2001: 83-144).

Teks sastra atau bagian-bagianya yang dicatat atau diucapkan akan mengandung interpretant. Setiap interpretasi teks tercatat, atau bagian-bagiannya, adalah interpretant. Interprestasi itu merupakan tanda bahasa, yakni tanda bahasa yang termasuk proses representasi dan interprestasi. Dalam interprestasi, kita pertama-tama memikirkan ekspresi bahasa yang melukiskan karya sastra yang dibahas (Zoest, 1993: 94).

\section{Analisis Stilistika terhadap Puisi "Tasbih"}

Puisi "Tasbih" merupakan puisi yang dapat dikelompokkan ke dalam puisi yang memiliki irama ritme. Artinya, ia tidak memiiliki irama yang terikat dan arti antar baris pun tidak bersifat terikat. Pada puisi ini, Emha tidak memunculkan kekuatan bunyi yang tinggi yang memunculkan efeks puitis begitu mendalam. Akan tetapi, Emha tetap memperhatikan keseimbangan bunyi antara kata-kata yang membentuk puisi tersebut.

Seperti yang diuraikan pada riwayat singkat Emha bahwa Emha adalah seorang penyair yang bersifat religius, kita dapat menilai puisi Tasbih sangat bersifat religius. Salah satu faktor yang menunjukkan hal tersebut adalah berdasarkan penggunaan kata dalam puisi tersebut. Emha banyak menggunakan kata-kata yag berkaitan dengan keagaaman, seperti tasbih, hamba, kekasih, bertakbir, kepada-Mu, bertabir, khalifah, keindahan-Mu, fakir, nafsu, dan ridha-Mu. Rereligius puisi Emha juga dapat kita lihat pada beberapa puisi dalam kumpulan puisi tersebut, yaitu 1) Puisi Hidayah, 2) Kabut, 3) Sauda- 
raku dalam Tuhan, 4) Fir'aun Picisan, 5) Tuhan Sudah Sangat Populer, dan 6) Cermin Ramadhan 2.

Tasbih merupakan alat yang untuk membantu menghitung jumlah kata tasbih yang telah diucapkan oleh seseorang. Menurut KBBI (2008:1408) bertasbih memiliki arti memanjatkan puji-pijian (subhanallah, 'maha suciAllah) kepada Allah. Kita dianjurkan selalu bertasbih kepada Allah. Dengan bertasbih, kita akan selalu mengingat-Nya. Orang yang selalu mengingatnya akanlah selalu berusaha melaksanakan apa yang dianjurkan oleh-Nya dan berusaha menjauhkan segala larangan-Nya.

Kata berikutnya, kata hamba. Menurut $K B B I$ (2008: 477), kata hamba merupakan kata yang biasa digunakan dalam kata sastra Melayu klasik. Penyair memilih kata hamba yang menimbulkan efek puisi yang religius. Kata hamba merujuk kata saya atau aku dengan tujuan merendahkan diri. Manusia merupakan makhluk yang rendah. Nuansa makna yang disampaikan oleh kata saya atau $a k u$. Manusia adalah hamba-hamba yang diciptakan Allah di atas bumi ini hanya untuk mengingat dan menyembah Allah. Ia tidak diciptakan untuk berkeluh-kesah karena ambisius mengejar kehidupan dunia yag fana. Ia harus dapat menyemimbangan antara kehidupan dunia yang fana dan kehidupan akhirat yang kekal.

Selanjutnya, penggunaan kata khalifa $h$ memberikan kesan religius tersendiri. Khalifah mempunyai tiga arti, yaitu 1) wakil (pengganti) Nabi Muhammad saw. Setelah Nabi wafat dalam urusan negara dan agama yang melaksanakan syariat atau hukum Islam dalam kehidupan negara, 2) gelar kepala agama an raja dalam negara Islam, dan 3) penguasa atau pengelola (KBBI, 2008: 692). Pada puisi tersebut makna yang dimaksudkan adalah makna yang pertama. Kita diharapkan menjadi khalifah di bumi ini dan melaksanakan tugas tersebut secara baik. Betapa nistanya seseorang bila mengaku sebagai hambaNya, tetapi ia begitu sombong atau congkak di atas bumi ini. Ia tidak mau melanjutkan perjuangan dan segala usaha yang telah dilakukan Nabi Muhammad.

Kata berikutnya, kata menyujudi pada baris kesepuluh sangat kental dengan nilai-nilai religi. Kata sujud memiliki dua arti, yaitu 1) berlutut serta meletakkan dahi ke lantai sambil membaca tasbih dan 2) pernyataan hormat dengan berlutut serta menundukkan kepala sampai ke tanah (KBBI, 2008: 1348). Pada puisi tersebut makna menyujudi adalah betapa seluruh makhluk di bumi ini takjud atas keindahan yang diciptakanAllah. Akan tetapi, tekadang sebagai manusia yang disibukkan berbagai kegiatan dunia lupa untuk sujud kepada-Nya. Emha yang berbagai puisinya selalu mengingatkan kepada kita tentang keberadaan Tuhan. Betapa Allahlah yang kita cari di dunia, mencari Allah berarti menyibukkan diri kita dengan Allah.

Di samping kata-kata yang mengandung regligi, Emha juga mampu memilih beberapa kata yang tidak langsung memperlihatkan nilai religi. Emha menggunakan kata melata. Kata melata memiliki makna berjalan dengan menempelkan perut ke tanah. Kata melata merupakan bentuk terikat, artinya tidak muncul kata lata. Kata itu memperlihatkan bahwa makhluk Allah yang hanya melata pun ikut bertakbir kepadaNya.

Pada baris ketujuh terdapat penggunaan kata rembulan yang berasal dari bahasa jawa. Pemilihan kata rembulan memberikan efek kepuitisan, penyair tidak memilih kata yang biasa kita gunakan, yaitu kata bulan. Di samping itu, penyair memilih kata seluruh yang bersinonim dengan kata semua. Pemilihan ini didasarkan dengan adanya kata namum, dan rembulan. Artinya ada kesamaan bunyi vokal $u$.

Beberapa pencitraan dimunculkan oleh Emha. Pada baris 14 sampai dengan 16 menimbulkan efek visual. Kita seakan-akan dapat melihat orang yang tidak ingin menghancurkan orang lain, melainkan mencoba mengoreksi dirinya. Pada baris 17 sampai dengan baris 24 mempelihatkan pencitraan visual. Kita seakan-akan dapat melihat sikap orang yang meremehkan nafsunya dan bersikap acuh terhadap apa yang dimilikiya. Kita juga digiring untuk melihat dunia yang gagah. Akan tetapi, keindahan itu adalah keindahan yang semu. Kita menemukan kemajuan dan kepintaran, tetapi keduanya terbentur dan terjebak pada kemunduran dan kebodohan. Semua itu hanya memperbudak manusia. Pada kata bertasbih Efek pencitraan yang ditimbulkan pada baris ini adalah efek pendengaran. Kita seakan-akan mendengar banyak hamba yang bertasbih. 
Untuk majas, Emha tidak banyak memanfaatkan aspek ini pada puisi takbir. Pada baris 6 sampai dengan 10 memperlihatkan penggunaan majas personifikasi. Hal itu terlihat pada seluruh alam, rembulan, cahaya, dan keremangan, angin, tanah, logam, pepohonan, suara, dan musik menyujudi keindahan-Mu. Ia menggambarkan bahwa semua makhluk yang dapat bergerak sendiri dapat bergerak seperti makhluk yang lain. Ia dapat sujud atas keindahan-Nya.

Emha tidak menggunakan pengulang kata depan di pada rangkaian kata di langit dan bumi. Artinya, penyair memperlihatkan keefektifan dalam beretorika. Penyair menggunakan rangkain kata yang menimbulkan efek kepuitisan yang. Ia menggunakan gaya bahasa hiperbola. Kita dapat melihatnya pada rangkain kata "para kekasih yang melata, yang merangkak, yang berjalan, yang duduk, yang berjalan". Penyair ingin menyampaikan semua makhluk ciptaan Allah yang dalam keadaan apapun atau dalam keadaan apapun akan bertakbir kepada Allah. Pada baris kedua dan kelima kita dapat melihat penggunaan kata bertasbih dan bertakbir. Hal itu memperlihatkan adanya kesejaran bentuk kata dalam bait tersebut.

Emha juga melakukan penyimpangan tata bahasa yang sengaja ia lakukan. Pada baris kesepuluh bait kedua ini terdapat penyimpangan dalam pembentukan kata menyujudi. Dalam KBBI, tidak terdapat kata tersebut. Hal tersebut dilakukan penyair untuk menimbulkan efek kepuitisan. Kita dapat melihat banyak digunakan kata-kata yang mengandung vokal $i$. Jadi, penyimpangan tersebut memang sengaja dilakukan oleh penyair. Pada baris kelima belas juga dapat kita temukan penyimpangan tata bahasa, ditemukan kata yang jarang kita gunakan dalam bahasa sehari-hari dan tidak terdapat dalam KBBI. Kata tersebut adalah mempertengkari. Kita dapat menemukan kata mempertengkarkan, bukan mempertengkari.

\section{Beberapa Interpretasi}

Kosakata yang dominan digunakan penyair adalah kosakata bahasa Indonesia. Walaupun terdapat beberapa kata yang berasal dari bahasa Arab,
Belanda, dan bahasa Sansekerta, kata-kata tersebut sudah diserap menjadi bahasa Indonesia. Penyair tidak menggunakan kosakata asing. Pada sajak yang lain yang berjudul Tuhan di Indonesia, penyair menggunakan kosakata yang berasal dari bahasa asing, yaitu bodyguard.

Penyair menggunakan kata ganti-Mu untuk menggantikan kata Tuhan. Tentunya, penyair menuliskan kata gantitersebut menggunakan hurufkapital. Artinya, berbeda dengan penulisan kata gantimu yang ditujukan untuk merujuk orang kedua.

Judul yang puisi ini adalah Tasbih. Judul ini memperlihatkan bahwa puisi ini adalah puisi sosial-religius. Salah satu sumber menyatakan bahwa Emha Ainun Nadjib adalah penyair yang bergulat dengan puisi yang bertemakan (1) puisi sosial (protes), (2) sosial religius, dan (3) bernapaskan mistis Islam (tasawuf). Dari 8000 puisi Emha, puisi tersebut didominasi oleh puisi yang berdimensi sosial-religius dan sosial mistis (http://whandi.net/ whandi/? pilih= new\&mod=yes\&aksi=lihatid).

Menurut Junus (dalam Hasanuddin, 2001: 151) tipografi yang digunakan dalam sajak ini adalah tipe a. Tipografi ini menggambarkan suasana sejajar dengan isinya bersamaan. Pada puisi ini memang terlihat isi yang disampaikan pada tiap bait bersifat saling berkaitan atau merupakan satu kesatuan. Misalnya, pada bait pertama menyampaikan semua manusia bertasbih dan bertakbir kepada Allah, sedangkan bait kedua menyampaikan bahwa selain manusia sebagai khlaifah juga sujd kepada Allah.

Puisi initidak memperlihat latar yang pasti. Akan tetapi, dengan adanya penggunakan kata barengbareng, penulis beranggapan bahwa puisi ini memiliki latar kejadian di Jakarta. Di samping itu, kita dapat menangkapnya latar tersebut dengan adanya bagian puisi yang berbunyi 'dunia begini gagah, kemajuan terbentur kemunduran, dan kepintaran terjebak kebodohan'. Kejadian ini dapat diasumsikan pada malam hari raya Iduladha atau Idulfitri. Asumsi tersebut dapat kita lihat dari penggunaan kata 'bertasbih dan bertakbir'. Kata-kata tersebut biasanya diucapkan pada dua hari raya tersebut.

Suasana yang terdapat dalam puisi ini adalah datangnya kesadaran manusia akan keberadaannya. 
Ia akan bertasih dan bertakbir mengucapkan Asma Allah. Bukan hanya manusia, melainkan seluruh ciptaannya juga sujud kepada-Nya. Pada malam Lailatur Qadar, semua tumbuh-tumbuhan sujud kepada merunduk atau sujud kepada Allah. Kemajuan yang telah dicapai ternyata tidak membawanya kepada kemajuan dan kepintaran yang digapai tidaklah membawa seseorang dapat bersikap cerdas. Kesadaran manusia itu muncul karena ternyata segala apa yang dimilikinya telah memperbudaknya. Misalnya, seseorang yang kaya, ia tergila-gila untuk mengejar dunia. Ia tidak sadar bahwa semua dari Allah.

\section{Simpulan}

Puisi Tasbih merupakan puisi Emha yang menggunakan kata-kata yang kental mengandung makna religius. Salah satu faktor yang menyebabkan kereligiusan tersebut muncul karena banyaknya manusia yang telah meninggalkan dunia kereligiusan. Selanjutnya, walaupun puisi ini tidak banyak mengandung majas, tetapi ia memiliki makna dalam. Kemampuan retorika Emha juga terlihat dengan jelas dalam puisi tersebut. Terakhir, Emha juga melakukan penyimpangan tata bahasa untuk menghasilkan efek puitis terhadap karyanya.

\section{Daftar Pustaka}

Hasanuddin.2001. Membaca dan Menilai Sajak. Bandung: Angkasa

Junus, Umar. 1989. Stilistika Satu Pengantar. Malaysia: Dewan Bahasa dan Pustaka

Keraf, Gorys. 2004. Diksi dan Gaya Bahasa. Jakarta: Gramedia.

Nadjib, Emha Ainun. 2001. Doa Mencabut Kutukan, Tarian Rembulan, Kenduri Cinta; Sebuah Trilogi. Jakarta: Gramedia.

Sarumpaet, Riris K. Toha. 2002. Apresiasi Puisi Remaja; Catatan Pengelola Cinta. Jakarta: Grasindo.

Sudjiman, Panuti dan Aart van Zoest. 1992. SerbaSerbi Semiotika. Jakarta: Gramedia.

Teeuw. 1984. Sastra dan Imu Sastera. Bandung: Pustaka Jaya

Tim Penyusun Kamus. 2008. Kamus Besar Bahasa Indonesia. Jakarta: Gramedia.

Royah. (2012). 'BiografiEmha Ainun Nadjib”, (http:/ /royahmadsketsa.wordpress), diakses 10 Juni 2012.

Merdeka.com (2013). "Biografi", (http://profil. merdeka.com/indonesia), diakses 13 Agustus 2013.

Wandhi (2012). "Emha Ainun Nadjib", (http:// whandi.net $/ \sim$ whandi $/$ ?pilih $=$ new\&mod $=$ yes\&aksi=lihatid) diakses 22 April 2012. 